\title{
Productivity and Profitability of Rain Fed Barley (Hordeum vulgare) Crop as Influenced by Variety, Fertility and Moisture Conservation
}

\author{
U.D. Awasthi, Shailendra Pratap Singh, P.K. Mishra, Brajesh Prajapati* \\ and Abhishek Singh \\ Department of Soil and Water Conservation CSAUAT Kanpur, India \\ *Corresponding author
}

\section{A B S T R A C T}

A field experiment was conducted during rabi season of 2011-12 and 2012-13 on rain fed barely (Hordeum vulgare) at Kanpur, Uttar Pradesh. The treatments

Keywords

Barley, Rain fed, Varieties, Fertility levels, Moisture conservation, Yield, Economics.

Article Info

Accepted:

26 May 2017

Available Online:

10 June 2017 comprised 18 combinations of 3 varieties (Haritma, Narmada and Lakhan), 3 fertility levels (N40 P20 K20, N60 P $30 \mathrm{~K} 30$ and N80 P40 K40 kg/ha) and 2 moisture conservation practices (Hand weeding 25 DAS and pre-E spray of pendimethaline@3.3L/ha). Variety 'Narmada' (27.38 and 28.65 q/ha) and 'Haritma' (27.49 and $27.62 \mathrm{q} / \mathrm{ha}$ ) being at par produced higher grain yield than 'Lakhan' (Rs. 17740 and 19795/ha). Among fertility levels, N80 P40 K40 recorded significantly highest grain yield (29.22 and $31.57 \mathrm{q} / \mathrm{ha})$ against lowest grain yield (22.78 and $21.56 \mathrm{q} / \mathrm{ha}$ ) and minimum net return (Rs. 16033 and 14290/ha) obtained at N40 P20 K20 fertility level during two different years. In case of moisture conservation practices, pendimethaline spray recorded higher grain yield (26.83 and $29.04 \mathrm{q} / \mathrm{ha}$ ) and earned higher net return (Rs. 22179 and 25534/ha) than hand weeding (26.01 and 25.73 q/ha grain yield and Rs. 19528 and 19223/ha net return). B: C ratio was also found higher in respective treatments.

\section{Introduction}

Barley (Hordeum vulgare) is an important rabi cereal crop in India. It has the widest ecological range of adaptation among the cereals and it is widely grown in temperate and sub-tropical regions of the country. It is generally grown on marginal and submarginal lands with low inputs where the conditions for wheat and other cereals are not suitable. In Uttar Pradesh, it is mostly grown on light textural soils which have low nitrogen and organic matter content with poor moisture retentive capacity. It is preferred by the resource poor farmers in the area due to its low input demand, lower cost of cultivation and resistance to drought condition. Barley has the great scope as food, feed, fodder and industrial crop. Now a days, the major use of barley grain is in brewing industries for manufacturing malt, which is used to make bear and industrial alcohol. The straw is used as fodder for cattle. Surplus and low grade grains are used as concentrate for livestock and poultry. The cultivation of barley in poor fertile un irrigated soils coupled with local varieties, inadequate nutrition and soil moisture stress are the major constraints in barley production. Improved crop varieties, no doubt have a great concern in crop 
production. Recently a number of improved barley varieties have been developed for different agro-ecological conditions of the state. If such varieties are cultivated with adequate supply of fertilizer nutrients and proper practices of soil moisture conservation are adopted, the productivity of barley in rain fed condition even on poor fertile soils may be certainly enhanced to satisfactory level. Keeping these points in view, the present study was taken up to select out most suitable barley variety, adequate fertility level and proper practice of soil moisture conservation from both productivity and profitability points of view of the farmers of central Uttar Pradesh.

\section{Materials and Methods}

The field experiment was conducted during winter (rabi) seasons of 2011-12 and 2012-13 at soil conservation and water management farm of C.S. Azad University of Agriculture and Technology, Kanpur. The soil of experimental field was sandy loam in texture and slightly alkaline in reaction $(\mathrm{pH}$ 7.8) having $0.33 \%$ O.C., $16.6 \mathrm{~kg} / \mathrm{ha} \mathrm{P}_{2} \mathrm{O}_{5}$ and 170 $\mathrm{kg} / \mathrm{ha} \mathrm{K} 20$.

The experiment was laid out in a split plot design with 3 replications. The main-plots comprised 6 combinations of 3 varieties (Haritma, Narmada and Lakhan) and 2 moisture conservation practices (dust mulch through hand weeding 25 DAS and Weedicide - pendimethaline @ 3.3 L/ha preemergence), whereas 3 fertility levels (N40+P20+K20, N60+P30+K30 and $\mathrm{N} 80+\mathrm{P} 40+\mathrm{K} 40 \mathrm{~kg} / \mathrm{ha}$ ) were tasted in subplots.

The requisite amount of $\mathrm{N}$ (urea), $\mathrm{P}$ (single super phosphate) and $\mathrm{K}$ (muri2ate of potash) fertilizers was applied in furrows below the seed at the time of seed sowing as per treatment. Sowing of barley varieties seed was done @ $100 \mathrm{~kg} / \mathrm{ha}$ behind country plough in furrows $22.5 \mathrm{~cm}$ apart on 29.10.2011 and 28.10, 2012 in two years. Pre-emergence spray of pendimethaline as per treatment plots was done 2-days after sowing with the help of knapsack hydraulic sprayer using a spray volume of 600 litres/ha.

For dust mulch, hand weeding with khurpi was done in respective plots at 25 DAS in each year. Other than treatments, the experimental crop was raised with recommended package of practices for rainfed barley crop. The observations under different treatment plots were recorded on various growth and yield attributes, crop yields and water use.

Economics of different treatments was also calculated on prevalent market rate of different inputs and price of grain and straw of crop produce. Benefit: cost ratio was calculated by dividing the gross return of each treatment by total cultivation cost of respective treatment. Water use efficiency under different treatments was calculated using standard method explained by Palaniappan and Sivaraman (1996).

\section{Results and Discussion}

\section{Growth and yield attributes}

Barley varieties differed significantly in all growth and yield attributes (Table 1). Variety 'Lakhan' produced significantly tallest plants while other two varieties remained at par with each other. Root growth in terms of number, depth and dry matter was observed significantly highest in 'Haritma' followed by 'Narmada' whereas 'Lakhan' recorded significantly lowest values of root parameters.

Number of spikes $/ \mathrm{m}^{2}$ and spike length were recorded significantly highest in 'Haritma' and lowest in 'Lakhan'. Significantly highest 
no of grains /spike and spike weight were recorded in 'Haritma' during both years followed by 'Lakhan'. Higher spike weight of 'Lakhan' than 'Narmada' might be attributed to higher 1000-grain weight which was found significantly highest in 'Lakhan' and lowest in 'Haritma'. Harvest index was recorded highest in 'Haritma' during 2011-12 but in following year, 'Narmada' and 'Lakhan' beinkg at par attained significantly higher harvest index than 'Haritma'. Varietal differences in growth and yield attributes seem to be due to their resistance capacity against limited soil moisture and adverse weather conditions which are mainly the genitical characters of any crop variety. Each increase in fertility level significantly increased almost all growth and yield attributes of crop plants. With each additional application of fertilizers availability of plant nutrients to crop might has improved the growth and yield attributes of barley. Being cereal crop, barley has better response to applied fertilizers particularly nitrogen (Saini and Thakur, 1999). Among moisture conservation practices, pendimethaline improved plant height, root depth, spike characters and harvest index significantly over hand weeding. It might be due to better weed control and increased availability of soil moisture to crop plants because of reduced crop-weed competition.

\section{Crop yield}

Variety 'Haritma' and 'Narmada' being at par produced significantly higher grain and straw yield of barley than 'Lakhan' during both years (Table 2). These higher yields might be attributed to better root growth and more developed yield attributes in 'Haritma' and 'Narmada' varieties. These varieties due to better root growth perhaps absorbed more soil moisture and nutrients which helped in proper growth and development of plants throughout crop season. Grain yield was found attributed mainly to number of spikes $/ \mathrm{m}^{2}$, number of grains/spike and spike weight (Table 1) On mean basis of two year results, varieties 'Haritma' and 'Narmada' produced 9.63 and $11.46 \%$ higher grain yield and 9.58 and $7.55 \%$ higher straw yield, respectively than the yields of variety 'Lakhan'. Varietal yield differences in barley have also been reported by Saini and Thakur (1999).

Increasing levels of fertility increased grain and straw yield significantly with up to highest level of N80 P40 K40. On mean basis of two years, N80 P40 K40 fertility increased grain yield by 37.1 and $8.0 \%$ and straw yield by 25.9 and $3.7 \%$ over N40 P20 K20 and N60 P30 K30 levels, respectively. These yields might be attributed to growth and yield attributes which also improved significantly with up to N80 P40 K40 fertility level. Our findings confirm the results of Puniya et al., (2015). Moisture conservation practice of pendimethaline spray could increase barley yield over hand weeding only during 2012-13 perhaps because of seasonal effect on weed control.

\section{Water-use}

Varieties did not show considerable difference in total water use but water-use efficiency (WUE) was computed significantly higher in varieties 'Haritma' and 'Narmada' than 'Lakhan' during both years. It might be attributed to higher grain yield of above varieties. Total water-use and WUE both improved with increasing levels of fertility up to N80 P40 K40. It might be due to the efficient utilization of applied nutrients at increased water-use by crop and vice-versa which improved the grain yield and thereby higher WUE. Out of moisture conservation practices, pendimetholine recorded significantly higher WUE than hand weeding only during 2012-13 which might be attributed to higher grain yield. These results may be supported by the findings of Awasthi et al., (1993). 
Table.1 Effect of varieties, fertility levels and moisture conservation practices on growth and yield attributes of barley

\begin{tabular}{|c|c|c|c|c|c|c|c|c|c|c|c|c|c|c|c|c|c|c|c|c|}
\hline \multirow[t]{2}{*}{ Treatments } & \multicolumn{2}{|c|}{$\begin{array}{l}\text { Plant height } \\
\text { (cm) }\end{array}$} & \multicolumn{2}{|c|}{$\begin{array}{c}\text { No. of } \\
\text { primary } \\
\text { roots/plant }\end{array}$} & \multicolumn{2}{|c|}{$\begin{array}{l}\text { Root depth } \\
\text { (cm) }\end{array}$} & \multicolumn{2}{|c|}{$\begin{array}{l}\text { Dry wt. of } \\
\text { roots/plant } \\
\text { (g) }\end{array}$} & \multicolumn{2}{|c|}{$\begin{array}{c}\text { No. of } \\
\text { spike/m² }\end{array}$} & \multicolumn{2}{|c|}{$\begin{array}{l}\text { Spike length } \\
(\mathrm{cm})\end{array}$} & \multicolumn{2}{|c|}{$\begin{array}{l}\text { No. of grains } \\
\text { per spike }\end{array}$} & \multicolumn{2}{|c|}{$\begin{array}{l}\text { Spike weight } \\
\text { (g) }\end{array}$} & \multicolumn{2}{|c|}{$\begin{array}{l}1000 \text { grain } \\
\text { wt. (g) }\end{array}$} & \multicolumn{2}{|c|}{$\begin{array}{c}\text { Harvest } \\
\text { Index }(\%)\end{array}$} \\
\hline & $\frac{N}{\stackrel{0}{O}}$ & $\begin{array}{l}N \\
\stackrel{0}{N} \\
1 \\
\omega\end{array}$ & $\frac{N}{\stackrel{0}{O}}$ & 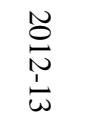 & $\begin{array}{l}\stackrel{N}{O} \\
\frac{1}{N}\end{array}$ & $\begin{array}{l}N \\
\stackrel{0}{N} \\
\stackrel{1}{\omega}\end{array}$ & $\begin{array}{l}\stackrel{N}{O} \\
\frac{1}{N}\end{array}$ & $\begin{array}{l}N \\
\stackrel{N}{N} \\
\stackrel{1}{\omega}\end{array}$ & $\frac{N}{O}$ & $\begin{array}{l}N \\
\stackrel{0}{N} \\
\stackrel{1}{\omega}\end{array}$ & $\frac{N}{\stackrel{O}{\Xi}}$ & $\begin{array}{l}N \\
\stackrel{0}{N} \\
\stackrel{1}{\omega}\end{array}$ & $\frac{N}{\stackrel{0}{O}}$ & $\begin{array}{l}\stackrel{N}{0} \\
\stackrel{N}{1} \\
\stackrel{1}{\omega}\end{array}$ & $\frac{N}{\stackrel{N}{\Xi}}$ & $\begin{array}{l}\stackrel{N}{0} \\
\stackrel{N}{\perp} \\
\omega\end{array}$ & $\frac{N}{\stackrel{O}{\Xi}}$ & $\begin{array}{l}N \\
\stackrel{0}{N} \\
\stackrel{1}{\omega}\end{array}$ & $\begin{array}{l}\stackrel{N}{O} \\
\frac{1}{N}\end{array}$ & $\begin{array}{l}\stackrel{N}{O} \\
\stackrel{N}{1} \\
\omega\end{array}$ \\
\hline \multicolumn{21}{|l|}{ Varieties } \\
\hline Haritma & 88.9 & 89.9 & 17.14 & 17.46 & $\begin{array}{c}30.0 \\
3 \\
\end{array}$ & $\begin{array}{c}29.7 \\
8 \\
\end{array}$ & $\begin{array}{c}2.63 \\
1 \\
\end{array}$ & 2.623 & 259.6 & 340.0 & 9.16 & 8.34 & 41.2 & 38.7 & $\begin{array}{c}2.20 \\
3 \\
\end{array}$ & 2.410 & $\begin{array}{c}44.2 \\
3 \\
\end{array}$ & $\begin{array}{c}43.5 \\
8\end{array}$ & $\begin{array}{c}34.2 \\
1\end{array}$ & 32.50 \\
\hline Narmada & 87.6 & 88.3 & 16.51 & 16.47 & $\begin{array}{c}29.3 \\
2 \\
\end{array}$ & $\begin{array}{c}28.9 \\
2 \\
\end{array}$ & $\begin{array}{c}2.50 \\
2 \\
\end{array}$ & 2.475 & 252.3 & 286.2 & 8.84 & 8.29 & 37.6 & 37.1 & $\begin{array}{c}2.11 \\
6\end{array}$ & 2.283 & $\begin{array}{c}45.1 \\
6\end{array}$ & $\begin{array}{c}44.3 \\
2\end{array}$ & $\begin{array}{c}32.6 \\
2\end{array}$ & 33.74 \\
\hline Lakhan & 95.3 & 96.3 & 16.00 & 16.12 & $\begin{array}{c}27.3 \\
1\end{array}$ & $\begin{array}{c}27.5 \\
8\end{array}$ & $\begin{array}{c}2.32 \\
3\end{array}$ & 2.420 & 232.0 & 261.7 & 8.71 & 7.82 & 38.6 & 37.2 & $\begin{array}{c}2.03 \\
9\end{array}$ & 2.348 & $\begin{array}{c}46.1 \\
9\end{array}$ & $\begin{array}{c}45.7 \\
0\end{array}$ & $\begin{array}{c}32.4 \\
3\end{array}$ & 33.31 \\
\hline S.Ed. \pm & 0.6 & 0.9 & 0.19 & 0.22 & 0.21 & 0.24 & $\begin{array}{c}0.04 \\
9 \\
\end{array}$ & 0.058 & 1.8 & 4.7 & 0.09 & 0.04 & 0.6 & 0.6 & $\begin{array}{c}0.01 \\
8 \\
\end{array}$ & 0.032 & 0.15 & 0.61 & 0.28 & 0.31 \\
\hline C.D. $(\mathrm{P}=0.05)$ & 1.4 & 2.0 & 0.43 & 0.49 & 0.46 & 0.54 & $\begin{array}{c}0.10 \\
9 \\
\end{array}$ & 0.129 & 4.1 & 10.4 & 0.20 & 0.08 & 1.3 & 1.3 & $\begin{array}{c}0.04 \\
1 \\
\end{array}$ & 0.080 & 0.33 & 1.35 & 0.62 & 0.70 \\
\hline \multicolumn{21}{|l|}{ Fertility levels } \\
\hline$\overline{\text { N40 P20 K20 }}$ & 83.8 & 84.8 & 14.21 & 15.54 & $\begin{array}{c}27.1 \\
2 \\
\end{array}$ & $\begin{array}{c}26.9 \\
8 \\
\end{array}$ & $\begin{array}{c}1.70 \\
2 \\
\end{array}$ & 2.335 & 218.3 & 274.5 & 8.24 & 7.93 & 34.4 & 32.1 & $\begin{array}{c}2.02 \\
5 \\
\end{array}$ & 2.230 & $\begin{array}{c}44.2 \\
6 \\
\end{array}$ & $\begin{array}{c}43.4 \\
8 \\
\end{array}$ & $\begin{array}{c}32.5 \\
3 \\
\end{array}$ & 31.82 \\
\hline N60 P30 K30 & 92.2 & 93.1 & 17.14 & 16.82 & $\begin{array}{c}29.2 \\
1\end{array}$ & $\begin{array}{c}28.4 \\
3\end{array}$ & $\begin{array}{c}2.14 \\
3\end{array}$ & 2.525 & 253.5 & 298.3 & 9.13 & 8.18 & 42.5 & 40.5 & $\begin{array}{c}2.12 \\
5\end{array}$ & 2.383 & $\begin{array}{c}45.2 \\
6 \\
\end{array}$ & $\begin{array}{c}44.7 \\
0\end{array}$ & $\begin{array}{c}33.2 \\
3\end{array}$ & 33.08 \\
\hline N80 P40 K40 & 95.8 & 96.7 & 18.20 & 17.68 & $\begin{array}{c}30.3 \\
3 \\
\end{array}$ & $\begin{array}{c}30.8 \\
9\end{array}$ & $\begin{array}{c}3.59 \\
1 \\
\end{array}$ & 2.658 & 272.1 & 315.0 & 9.50 & 8.34 & 40.4 & 40.5 & $\begin{array}{c}2.28 \\
0 \\
\end{array}$ & 2.428 & $\begin{array}{c}46.0 \\
6 \\
\end{array}$ & $\begin{array}{c}45.4 \\
2 \\
\end{array}$ & $\begin{array}{c}35.5 \\
0 \\
\end{array}$ & 34.65 \\
\hline S.Ed. \pm & 0.8 & 0.9 & 0.17 & 0.20 & 0.23 & 0.27 & 0.38 & 0.047 & 2.0 & 3.9 & 0.10 & 0.04 & 0.5 & 0.6 & $\begin{array}{c}0.02 \\
6 \\
\end{array}$ & 0.030 & 0.19 & 0.64 & 0.38 & 0.25 \\
\hline C.D. $(\mathrm{P}=0.05)$ & 1.6 & 1.8 & 0.36 & 0.42 & 0.48 & 0.56 & 0.79 & 0.097 & 4.1 & 8.1 & 0.20 & 0.08 & 1.1 & 1.3 & $\begin{array}{c}0.05 \\
3 \\
\end{array}$ & 0.061 & 0.40 & 1.31 & 0.79 & 0.51 \\
\hline \multicolumn{21}{|l|}{$\begin{array}{ll}\text { Moist. } & \text { Cons. } \\
\text { Pract. } & \\
\end{array}$} \\
\hline Hand weeding & 88.2 & 89.0 & 16.43 & 16.74 & $\begin{array}{c}28.4 \\
1\end{array}$ & $\begin{array}{c}28.2 \\
3 \\
\end{array}$ & $\begin{array}{c}2.44 \\
3 \\
\end{array}$ & 2.514 & 245.1 & 286.4 & 8.79 & 8.07 & 37.7 & 36.4 & $\begin{array}{c}2.09 \\
9 \\
\end{array}$ & 2.300 & $\begin{array}{c}45.1 \\
0\end{array}$ & $\begin{array}{c}44.4 \\
3 \\
\end{array}$ & $\begin{array}{c}32.7 \\
2\end{array}$ & 32.30 \\
\hline Pendimethaline & 93.0 & 94.0 & 16.72 & 16.62 & $\begin{array}{c}29.4 \\
3 \\
\end{array}$ & $\begin{array}{c}29.3 \\
0 \\
\end{array}$ & $\begin{array}{c}2.53 \\
1 \\
\end{array}$ & 2.498 & 250.5 & 305.4 & 9.09 & 8.23 & 40.5 & 38.9 & $\begin{array}{c}2.14 \\
8 \\
\end{array}$ & 2.394 & $\begin{array}{c}45.3 \\
8 \\
\end{array}$ & $\begin{array}{c}44.6 \\
4 \\
\end{array}$ & $\begin{array}{c}33.5 \\
2 \\
\end{array}$ & 34.06 \\
\hline S.Ed. \pm & 0.5 & 0.7 & 0.15 & 0.18 & 0.18 & 0.20 & $\begin{array}{c}0.03 \\
5 \\
\end{array}$ & 0.047 & 1.49 & 3.8 & 0.07 & 0.03 & 0.5 & 0.5 & $\begin{array}{c}0.01 \\
5 \\
\end{array}$ & 0.026 & 0.12 & 0.50 & 0.23 & 0.26 \\
\hline C.D. $(\mathrm{P}=0.05)$ & 1.1 & 1.7 & NS & NS & 0.41 & 0.44 & $\begin{array}{c}0.07 \\
8\end{array}$ & NS & 3.32 & 8.5 & 0.16 & 0.07 & 1.1 & 1.1 & $\begin{array}{c}0.03 \\
3\end{array}$ & 0.057 & NS & NS & 0.51 & 0.57 \\
\hline
\end{tabular}


Table.2 Effect of varieties, fertility levels and moisture conservation practices on yield, water use and economics of barley

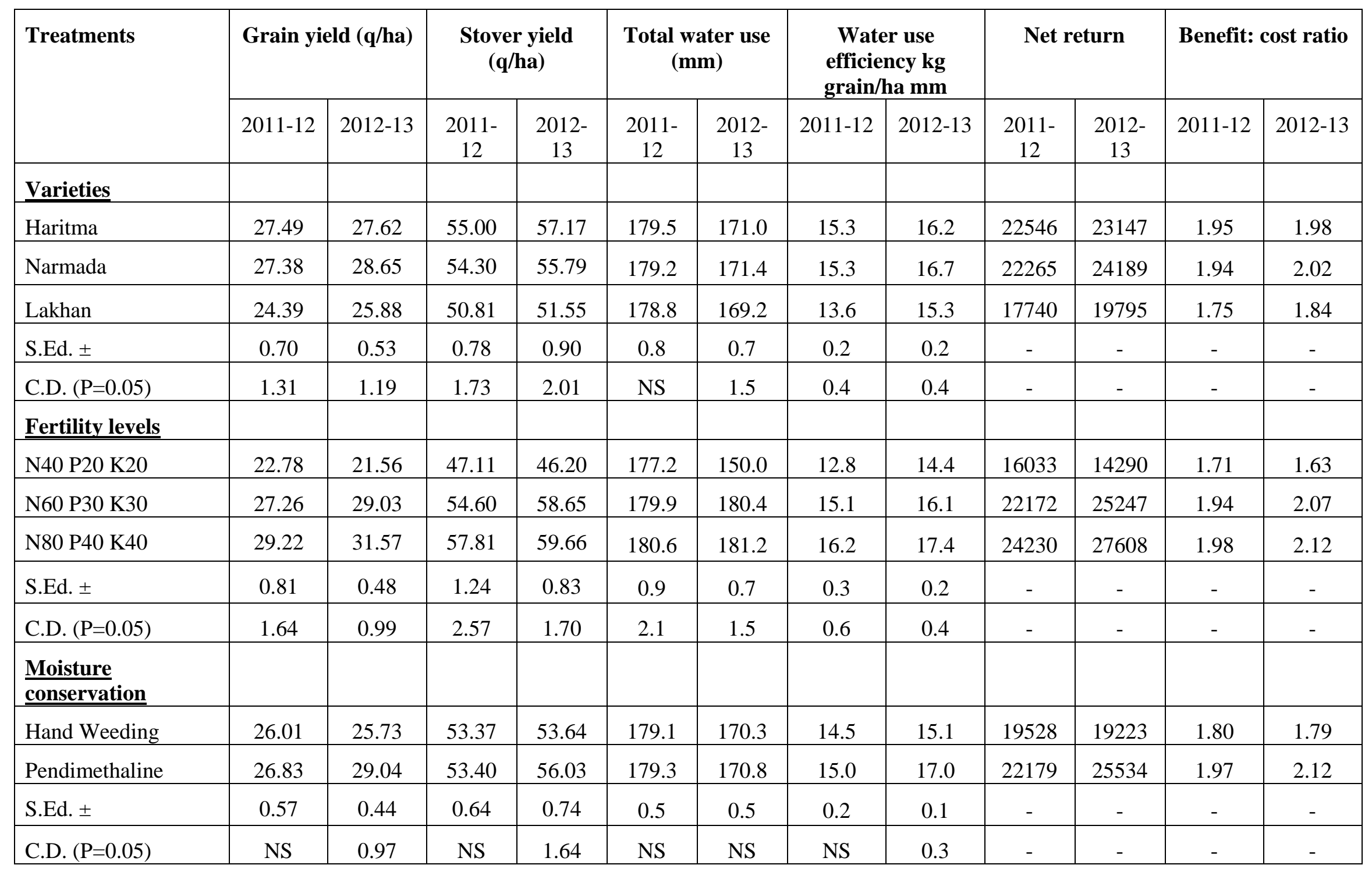




\section{Economics}

The varieties 'Haritma' and 'Narmada' being almost at par recorded considerably higher values of net return and $\mathrm{B}$ : $\mathrm{C}$ ratio during both years. On mean basis of two years data, 'Narmada' and 'Haritma' earned Rs. 4459.5 and $4079.0 /$ ha or 23.8 and $21.7 \%$ more net return, respectively than the variety 'Lakhan'. It might be attributed to grain and straw yield because cost of cultivation was same for all varieties. Net return also increased with increasing fertility up to N80 P40 K40 level which earned Rs. 10757.5 and 2209.5/ha more or 71.0 and $9.3 \%$ higher over N40 P20 K20 and N60 P30 K30 levels, respectively on mean basis of 2-year data B: C ratio followed the same trend of net return. Higher net returns might be attributed to higher grain and straw yields. The margin of yield increase was much higher than cost involved in additional fertilizer, thus net return and $\mathrm{B}$ : C ratio both improved with fertility. These results are in corroboration with the findings of Meena et al., (2012). Among moisture conservation practices, pre-E spray than hand weeding. On mean basis of 2-year data, pendimethaline spray earned Rs. 4481/ha or $23.1 \%$ higher net return than hand weeding. It might be attributed to lower cost involved in pendimethaline spray and higher crop yield.

These results may be concluded that for rainfed condition of central Uttar Pradesh, barley varieties 'Narmada' and 'Haritma' along with $80 \mathrm{~kg} \mathrm{~N}+40 \mathrm{~kg} \mathrm{P}_{2} \mathrm{O}_{5}+40 \mathrm{~kg}$ $\mathrm{K}_{2} \mathrm{O} / \mathrm{ha}$ and pre-emergence spray of pendimethaline@ @ 3.3 litres/ha are equally effective for higher productivity and profitability.

\section{References}

Awasthi, U.D, Bhan, S. and Uttam, S.K. (1993). Root development and moisture use in wheat (Triticum aestivum) and Barley (Hordeum vulgare) as influenced by crop variety and nitrogen. Indian Journal of Agronomy, 38 (4): 559-561.

Meena, L.R. Mann, J.S. and Meena, S.L. (2012). Effect of levels and mode of nitrogen application on dual purpose barley (Hordeum vulgare) under semiarid condition. Indian Journal of Agronomy, 57 (2): 168-170.

Palaniappan, S.P. and Sivaraman, K. (1996). Cropping systems in the tropics: Principles and management, pp. 28-35, New Age International Publishers, New Delhi-110002.

Puniya, M.M., Yadav, S.S. and Shivram, A.C. (2015). Productivity, profitability and nitrogen use efficiency of barley (Hordaem vulgare) as influenced by weed management and nitrogen fertilization under hot semi-arid ecologies of Rajasthan. Indian Journal of Agronomy, 60 (4): 564-569.

Saini, J.P. and Thakur, S.R. (1999). Response of barley (Hordeum vulgare) varieties to nitrogen under dry temperate conditions. Indian Journal of Agronomy, 44 (1): 123-125.

\section{How to cite this article:}

Awasthi, U.D., Shailendra Pratap Singh, P.K. Mishra, Brajesh Prajapati and Abhishek Singh. 2017. Productivity and Profitability of Rain Fed Barley (Hordeum vulgare) Crop as Influenced by Variety, Fertility and Moisture Conservation. Int.J.Curr.Microbiol.App.Sci. 6(6): 29522957.

doi: https://doi.org/10.20546/ijcmas.2017.606.351 